\title{
PUBLIC SATISFACTION INDEX SURVEY AT DEPARTMENT OF INVESTMENT AND ONE STOP INTEGRATED SERVICE IN SUBANG REGENCY
}

\author{
Kamal Alamsyah \\ Faculty of Social Sciences and Politics, Universitas Pasundan \\ apih.amay007@gmail.com
}

\begin{abstract}
In accordance with the mandate of the law, changes in the system of governance in the region have changed from a centralized model to decentralization. This is characterized by the devolution of most government affairs to the region including the implementation of fiscal decentralization directed to finance the administration of government affairs. Law Number 25 Year 2009 concerning Public Service and Regulation of the Minister for Empowerment of State Apparatus and Bureaucracy Reform Number 16 Year 2014 on Guidelines for the Survey of the Public Satisfaction Index on Public Service Implementation recommends that every service provider conduct a public satisfaction index (IKM) survey periodically. The purpose of the study was to measure public satisfaction with public services at Department of Investment and One Stop Integrated Service (DPMPTSP), Subang Regency. This research used deductive quantitative method. Primary data is obtained through direct survey and interview. Data obtained using a questionnaire with closed questions. The sample type is purposive sampling as many as 240 people. The purpose of the survey of IKM on public service is intended to get opinion of the public regarding the quality of public services in DPMPTSP. The IKM survey is conducted on four service units, namely Building Permit (IMB), Business License (SIUP), Company Registration Certificate (TDP) and Industrial Registration Certificate (TDI). Measurement of IKM survey of public services using PERMENPANRB Number 16 Year 2014 which consists of 9 aspects: 1) Requirements; 2) Procedures; 3) Time of service; 4) Costs / Tariffs; 5) Product Specifications Type of Service; 6) Executing Competencies; 7) Executive Conduct; 8) Service Notice; and 9) Complaint Handling, Suggestions and Feedback. The results of the IKM are in the category of Quality of Service Performance B (Good).
\end{abstract}

Keywords: Decentralisation, Public Satisfaction, Public Satisfaction Index.

\section{Introduction}

In accordance with the mandate of the law, changes in the system of governance in the region have changed from a centralized model to decentralization. There is an inevitability and paradox about the decentralization of public services in a world that is increasingly centralized and global at another level. Centralization and decentralization have to evolve together to counteract each other's extremes (Bruce, 2009:12). According to the UNDP that decentralisation is the logical application of the core char- acteristics of good governance at the sub-national or local levels (Alam, 2015:4). Article 1(e) of Law No.22/1999 on Regional Governments defines desentralisasi as the delegation of authority to govern and regulate, from the central government to regional governments within the unitary State of the Republic of Indonesia (Ewing-Chow and Losari, 2105: 244). This is characterized by the devolution of most government affairs to the region including the implementation of fiscal decentrali- 
zation directed to finance the administration of government affairs. Local governments have a responsibility to provide excellent service to the community by presenting public service policies that are not only based on providers, but also aspects of customer service. Public service is a term commonly used to mean services provided by government to its citizens and also directly through the public sector or through the budgetary provision of private sector services (Hardianto and Adiwidjaja, 2015:17). Many public services are financed through taxation rather than through the direct charging of customers (Doherty and Horne,2002:5).

The low awareness of problems of some government officials and the lack of innovation in public services and weak local government motivation in improving service quality is one of the most crucial issues in public service. Public services generally relate to public goods and collective goods services provided by government and common-pool goods. In fact, public services is also marked by the weak knowledge of the public regarding the minimal service performed by the government. Law Number 25 Year 2009 regarding Public Service and Regulation of the Minister of State Apparatus Empowerment and Bureaucracy Reform Number 16 Year 2014 on Guidelines for Survey of Public Satisfaction Index on Public Service Provision which mandates that every service provider periodically conduct a survey of public satisfaction index (Indeks Kepuasan Masyarakat hereinafter IKM).
Subang Regency government always strive to make various efforts to improve the quality of public services. The main consideration that Subang Regency government is one of the leading sectors in public service. Therefore, in order to achieve the improvement of the quality of public services, a measurement that can be accounted for normatively and academically. Alamsyah states that: "Knowing the level of performance of the organization is the feedback for the leadership to determine the policy to be conducted in order to improve subsequent performance (2017:16). Measurements referred to have four main objectives:" 1) Obtaining value satisfaction index; 2) Mapping the quality of public services; 3) Capturing public expectations of public services; and 4) Developing strategies to improve the quality of public services. Measurement results will be used as a reference and consideration in determining the strategy to improve public services in Subang Regency, especially services implemented by Department of Investment and One Stop Integrated Service (Dinas Penanaman Modal dan Pelayanan Terpadu Satu Pintu, hereinafter DPMPTSP).

\subsection{Public Service}

Shah states that local or municipal governments are directly responsible for a range of public services for which fees or prices tend not to be used. Local streets and roads, street lighting, fire and police protection, and neighborhood parks are almost always funded from local taxes, grants from senior govern- 
ments, and other locally generated revenues (2005:118); According to Zeithaml and Bitner that service are usually defined as "deeds, processes, and performances; Ramaswamy described service as business transaction that take place between a donor (service provider) and receiver (customer) in order to produce outcome that satisfies the customer (Akinbaode et al, 2012:185). For Kotler (2003) public service is any action or deed which can be offered by one party to another, which is essentially intangible and does not result in the possession of something. The delivery of public services is typically a highly complex undertaking, which involves a large number of transactions between service providers and recipients (Brajaktari, 2016:6).

Public service is the clearest indicator of how far the government is able to provide the best service to the community. Public service may be defined as any form of services, either in the form of public goods or public services which are the responsibility and carried out by the Government Agencies. In essence public service is the main task in state administration conducted by the state apparatus. The characteristics of public services are the following: The service are bought necessary for the public good. They are available to and utilized by the general public" (Akinbaode et al., 2012:185). Meanwhile, the government only helps people to help themselves which is the principle of self-help or steering rather than rowing in the idea of Reinventing Government. Osborne defined public service as uncoupling steering and rowing was the first principle outlined in
Reinventing Government, which we called "Catalytic Government" (Osborne, 2007:5); Wiig states that public services must address issues and requirements relevantly, competently, and in a timely manner, and consume minimal resources. They should also deal appropriately and expeditiously with unexpected challenges and disasters (Wiig, 2002:225).

\subsection{Public Service Performance Measurement}

According to Akinbaode et al that survey result as feet back for service improvement of citizen's feet back becomes an effective means for improving the performance of public service as it can be used to demand accountability fro the providers, especially when there are no alternatives due to regulation in delivery services (2012:183). Out comes is the highest value or service advantages for the user as a blend of user needs in achieving the goals that have been set. While the level of service is the volume of service relation to the target population that can be reached. Take-up (the proportion of target population using services) here is a calculation based on the highest usage indicator of the quality of service provided. Akinbaode (2012) in assessing Government performance should be done comprehensively with reference to four dimensions: (1) the level of human resource commitment to the organization; (2) the level of government orientation to the community; (3) the level of liveliness as a service producer; (4) the level of bureaucratic order. Parasuraman (2002) describes it as a flower chart with eight petals that analogize eight service 
supplements, namely: 1) Information; 2) Consultation; 3) Ordertaking; 4) Hospitality; 5) Caretaking; 6) Exceptions; 7) Billing; 8 Payment. According to Parasuraman (2002), there are two dimensions and four sub-classifications of services depending on who or what the direct recipient of the service is, whether it is "people" or "things"; and what the nature of the service act is, whether it is "tangible" or "intangible" (Akinboade et al., 2012:185).

\subsection{Public Service Indicators}

Parasuraman et al. (2000) proposed several indicators of public satisfaction, namely: a) tangible, for example in the form of facilities, facilities of office such as computerization, administration, waiting room, place of information and so forth; b) reliability, namely the ability and reliability to provide reliable services; c) responsiveness which is the ability to help and provide services quickly and accurately, and responsive to consumer desires; d) assurance, namely the ability and friendliness and courtesy of employees in ensuring consumer confidence; e) empathy, which is firm but attentive to the consumer. Therefore, quality is important aspect of public service. Donelly identifies the specific characteristics of public sector that complicate quality principle's implementation. He claims that the quality itself has a completely different meaning in the public compared to the private sector. That is why quality improvement in the public sector limited to the improvement of the internal organization's operations, instead of improving the final services in order to offer new and more services (Vacaloupoulou, 2013:747).

\subsection{Servqual}

The SERVQUAL model proposes that customers evaluate the quality of service on five distinct dimensions: reliability, responsiveness, assurance, empathy, and tangibles (Ramseook-Munhurrun et al, 2010:39). According to Parasuraman et $a l$. that service quality is the difference between expectation or expectancy with perceived service or commonly known through five service quality gaps. However, the application of the SERVQUAL approach should also consider the measurement of two related dimensions: 1) Costumer Gaps; and 2) Provider Gaps. The gap of the recipient of service or customer (gap) is the difference in the magnitude between perception and customer expectations. Customer perceptions are subjective judgments. The assessment is strongly influenced by many factors, both from product characteristics and internal individuals who conduct the assessment. Perception is an experience experienced by users of public services, while expectations are ideal conditions that are expected in the public service at a later date. Parasuraman $e t$ al (2000: 62) describes the factors that affect customer expectations of service as follows: 1) Word of mouth; 2) Personal needs; 3) past experience; 4) External communication. According to Parasuraman (2002) there are five gaps in service quality: 1) The gap between consumer expectations and management perceptions; 2) The gap between management's perception of consumer expectation and service quality specifica- 
tion; 3) The gap between service quality specification and the reality of lower service delivery; 4) The gap between the reality of delivery service quality and communication with customers; 5) The gap that occurs in consumers' "expectations" with "perceptions" about service. The key factors causing the gap are: (a) the company or organization is less oriented to market research or less use of research findings that serve to make decisions about wants, or complaints from consumers, (b) inadequacy of upward communication ie the flow information linking service at the front line service level to the top level (miscommunication), and (c) the number of levels within the organizational structure will distance the decision from top to bottom or vice versa. SERVQUAL consists of ten indicators of service performance, namely: 1) Tangible; 2) Reliability; 3) Responsiveness; 4) Competence; 5) Courtesy; 6) Credibility; 7) Security; 8) Access; 9) Communication; 10) Understanding the Customer.

\subsection{Public Satisfaction Index (IKM)}

In the Decree of the Minister of Administrative Reform of the State of the Republic of Indonesia Number: Kep./25/M.PAN/2/2004 on the Public Satisfaction Index (IKM) has been explained that public satisfaction index (IKM) is data and information about the level of public satisfaction obtained from the measurement quantitatively and qualitatively on the public's opinion in obtaining services from the public service providers by comparing their expectations and needs ". Parameters used in the Decree of the Minister of
Administrative Reform of the State Number: KEP / 25 / M.PAN / 2/2004 on General Guidelines for Compilation of Public Satisfaction Index of Government Institution Service Unit, including: Service Procedure, Service Requirements, Clarity of Service Officer, Discipline of Service Officer, Responsibilities of Service Officers, Ability of Service Officers, Speed of Service, Justice received services, Courtesy and hospitality of service personnel, Service cost, Certain Service schedule, Service Cost Certainty, Environmental Comfort, and Security service

Minister of Administrative Reform and Bureaucracy Reform issued Ministerial Regulation No. 16 of 2014 on Guidelines for Public Satisfaction Survey on Public Service Delivery. The regulation states that "Community Satisfaction Survey is a comprehensive measurement of activities on the level of community satisfaction derived from the measurement of public opinion in obtaining services from public service providers".

Public service unit is a work unit / service office in government agencies, which directly or indirectly provide services to recipients of services. In the Regulation of the Minister of State Apparatus Empowerment and Bureaucracy Reform No. 16 of 2014 on Guidelines for Public Satisfaction Surveys on Public Service Provision, it is also explained that the target of the Satisfaction Survey is as follows: a) Encouraging community participation as a service user in assessing the performance of service providers; b) Encouraging service providers to improve service quality; c) Encourage service providers to be more innovative 
in organizing public services. In addition, PERMENPANRB No 16 of 2014 also explained that the scope of the Community Satisfaction Survey covers 9 (Nine) important aspects. As for the 9 (Nine) indicators can be explained as follows: 1) Requirements; 2) Procedures; 3) Service time; 4) Cost / Tariff; 5) Product Specification Type of Service; 6) Executing Competencies; 7) Executive Conduct; 8) Service Notice); 9) Complaint Handling, Suggestion and Feedback. Parasuraman (2002)

\section{Method}

This research used deductive quantitative method. Qualitative method which concerned with developing explanations of social phenomenal. It aims to help us to understand the social world in which we live and why things are the way they are (Hancock et al. 2009:7). Qualitative research is characterized by generate words, rather than numbers, as data for analysis (Bricki and Green,2007:2). Primary data is obtained through direct survey and interview. The data were obtained using questionnaires with closed questions. The sample type was purposive sampling with a total sample of 240 people. The scope of this IKM survey is on public service units at DPMPTSP, Subang Regency, consisted of four types of services, namely: 1) Building Permit Service (IMB); 2) SIUP Service (SIUP); 3) Industrial Registration Certificate Service (TDI); and 4) IKM survey at DPMPTSP, Subang Regency, is as follows: 1) Result of measurement of Expectation Index and IKM for performance of four public services with of analysis of conformity
Company Registration Certificate Service (TDP). Each service is taken as many as 60 people. Samples taken from the population must be representative or can actually represent the population. Population in this research is all service user of public service at DPMPTSP in Subang Regency. This survey aims to determine the performance level of the service provider unit as reference material to establish the policy of improving the quality of public services at DPMPTSP, Subang Regency.

Research on IKM at DPMPTSP, Subang Regency, will be implemented by using the following approaches: 1) Field survey conducted to obtain primary data and information through observation, direct interview with all stakeholders; 2) The institutional approach taken to obtain secondary data and information from institutions, agencies, and offices; 3) Literature study on regulation provisions, legislation, policy, research study and other. The main objectives of the survey are: a) To know the weakness and lack of service providers at DPMPTSP; b) To know the performance of DPMPTSP services; c) Know the value of IKM on four service units at DPMPTSP.

\section{Result and Discussion}

\subsection{Results of IKM Survey at DPMPTSP, Subang Regency}

of expectancy and reality by using Kartesius diagram; 2) Characteristics of respondents and their impact on the value of IKM; 3) Result of expectation index measurement and IKM along with 
result of conformity analysis between level of expectation and reality in each unit of public service; 4) Gap analysis between expectation and reality on public service performance in each unit of public service. The questionnaire used 9 indicators of assessment measures of the Community Satisfaction Index (IKM) which comprised / consisted of: 1) Requirements; 2)
Procedures; 3) Service time; 4) Cost / Tariff; 5) Product Specification Type of Service; 6) Executing Competency; 7) Executive Conduct; 8) Service Notice; 9) Complaint Handling, Suggestion and Feedback. Table 1 shows the recapitulation results of IKM calculations on each element of service in DPMPTSP as shown in Table 1.

Table 1. IKM Calculation Results on Four Service Types at DPMPTSP

\begin{tabular}{clccc}
\hline No & Service Type & Expectation Index & Satisfaction Index & Quality Service \\
\hline 1 & SIUP Service & 92,41 & 79,23 & B \\
\hline 2 & TDI Service & 90,60 & 80,34 & B \\
\hline 3 & IMB Service & 95,51 & 79,32 & B \\
\hline 4 & TDP Service & 94,44 & 80,66 & \\
\hline & Average & 93,24 & 79,89 & B \\
\hline & IKM & & $\mathbf{3 , 2 0}$ & \\
\hline
\end{tabular}

Source: Survey Results, Year 2017.

Based on Table 1 that the results of analysis of Expectation Index and IKM to four types of services at DPMPTSP Subang Regency average value of IKM of 93.24. The highest Expectation Index value on the type of IMB service with an Expectation Index value of 95.51. While the lowest is the type of service TDI of 90.60. Based on MenPAN Decree No.KEP / 25 / M.PAN / 2004 the quality of public service quality service consists of: 1) Category A quality service (excellent performance) IKM conversion interval value equal to 81.26 to $100.00 ; 2$ ) Category B service quality (good performance) value of IKM conversion interval equal to 62.51 to 81.25 ; 3) Quality of service category C (poor performance) value of IKM conversion interval equal to 43.76 to 62.50 ; 4) Quality of service category D (performance is not good) IKM conversion interval value equal to 25.00 to 43.75 . The average of IKM in four types of services held by DPMPTSP is 3.20 including category $B$ with the assessment of "Good" service performance.

\subsection{Gap of Public Expectations on Satisfaction of Four Types of Public Service at DPMPTSP}

To measure the level of public satisfaction of public services organized by DPMPTSP conducted by Gap Analysis. The Gap Analysis results are shown in Table 2 below.

Table 2. IKM Calculation Results of Four Types of Services at DPMPTSP

\begin{tabular}{cccccc}
\hline No & Service Type & Expectation Index & Satisfaction Index & Quality Service & Gap \\
\hline 1 & SIUP Service & 92,41 & 79,23 & B & $(13,18)$ \\
\hline
\end{tabular}


Journal Sampurasun : Interdisciplinary Studies for Cultural Heritage

Vol. 04, Number 02, December 2018

\begin{tabular}{llllll}
\hline 2 & TDI Service & 90,60 & 80,34 & B & $(10,27)$ \\
\hline 3 & IMB Service & 95,51 & 79,32 & B & $(16,19)$ \\
\hline 4 & TDP Service & 94,44 & 80,66 & B & $(13,78)$ \\
\hline & Average & 93,24 & 79,89 & & 13,35 \\
\hline IKM & & $\mathbf{3 , 2 0}$ & B & \\
\hline
\end{tabular}

Source: Survey Results, Year 2017.

Based on Table 2 the gap between expectations and service satisfaction averaged 13.35. That the public expectation of four types of services DPMPTSP, Subang Regency, still exceeds that felt by the community. The greatest gap value is the type of IMB service, which is 16.19. These results indicate that IMB services have not met / approached expectations. TDP service type has a gap value of 13.78. Type of service SIUP has a gap value of 13.18. TDI service type has a gap value of 10.27. Based on Spiderweb analysis that four types of service have different gaps. Visually the type of IMB service has a distant distance compared to other types of services. This explains that the service gap is relatively large. The type of service that has the smallest gap value is the TDI service. The result explains that the satisfaction level of TDI service is close to Expectation Index.

\section{Satisfaction Index of Service Unit}

To see the specific needs to be done also the analysis and discussion related to community satisfaction on each type of service under study. The analysis results of each type of service surveyed in DPMPTSP, Subang Regency, can be explained below.

\section{Validity and Reliability Test}

Before IKM analysis for IMB service type, it is firstly tested the validity and reliability. The validity test in this survey took 60 respondents. The results of validity and reliability test of research data are described in the Table 3 below:

Table 3. Validity Test Result

\begin{tabular}{|c|c|c|c|c|}
\hline No & Service Elements & $\mathbf{R}$ & R min & Result \\
\hline 1 & Terms & 0,30 & 0,46 & Valid \\
\hline 2 & Procedure & 0,30 & 0,62 & Valid \\
\hline 3 & Service Time & 0,30 & 0,75 & Valid \\
\hline 4 & Cost / Tariff & 0,30 & 0,52 & Valid \\
\hline 5 & Product Specification Type of Service & 0,30 & 0,63 & Valid \\
\hline 6 & Implementing Competencies & 0,30 & 0,47 & Valid \\
\hline 7 & Executing Behavior & 0,30 & 0,56 & Valid \\
\hline 8 & Service Notices & 0,30 & 0,61 & Valid \\
\hline 9 & Handling complaints, suggestions and feedback & 0,30 & 0,58 & Valid \\
\hline
\end{tabular}

Source: Survey Results, Year 2017.

Based on the above Table 3 the service element that becomes the parameter of
IKM is valid. The level of reliability of this research data is reliable. 


\subsection{IKM Calculation Result of IMB} Service

Calculation of IMB service element at DPMPTSP consists of nine indicators.
The calculation of Satisfaction Index and Expectation Index can be seen in the Table 4 below.

Table 4. Public Satisfaction Index (IKM) of Building Permit Services (IMB)

\begin{tabular}{|c|c|c|c|}
\hline No & Service Element & Expectation Index & Satisfaction Index \\
\hline 1 & Terms & 3,97 & 3,15 \\
\hline 2 & Procedure & 3,78 & 3,27 \\
\hline 3 & Service Time & 3,95 & 3,22 \\
\hline 4 & Cost / Tariff & 3,85 & 3,17 \\
\hline 5 & Product Specification Type of Service & 3,87 & 3,10 \\
\hline 6 & Implementing Competencies & 3,68 & 3,28 \\
\hline 7 & Executing Behavior & 3,77 & 3,13 \\
\hline 8 & Service Notices & 3,92 & 3,22 \\
\hline \multirow[t]{6}{*}{9} & Handling complaints, suggestions an feedback & 3,63 & 3,05 \\
\hline & Highest Scores & 3,97 & 3,28 \\
\hline & Lowest Score & 3,63 & 3,05 \\
\hline & Average IKM & 3,82 & 3,17 \\
\hline & Conversion Value & 95,51 & 79,32 \\
\hline & Quality of Service & A & $\mathrm{B}$ \\
\hline
\end{tabular}

Source: Survey Results, Year 2017

Based on the recapitulation of IKM value for IMB services obtained result of 3.17 or 79.32 (conversion result). IKM for IMB services is classified into category B as "service performing well".

\subsection{The Gap of Public Expectations on the Satisfaction of IMB Ser- vice at DPMPTSP}

To measure the level of community satisfaction of IMB services organized by DPMPTSP conducted by Gap Analysis. The results of Gap Analysis of IMB services organized by DPMPTSP as shown the Table 5 below.

Table 5. Gap between Expectation and Satisfaction of the Community

\begin{tabular}{clccc}
\hline No & \multicolumn{1}{c}{ Service Element } & Index Expectation & Index Satisfaction & Gap \\
\hline 1 & Terms & 3,97 & 3,15 & $(0,82)$ \\
\hline 2 & Procedure & 3,78 & 3,27 & $(0,52)$ \\
\hline 3 & Service Time & 3,95 & 3,22 & $(0,73)$ \\
\hline 4 & Cost / Tariff & 3,85 & 3,17 & $(0,68)$ \\
\hline \multirow{2}{*}{$\begin{array}{l}\text { Product Specification Type of } \\
\text { Service }\end{array}$} & 3,87 & 3,10 & $(0,77)$ \\
\hline
\end{tabular}


Journal Sampurasun : Interdisciplinary Studies for Cultural Heritage

Vol. 04, Number 02, December 2018

\begin{tabular}{clccc}
\hline No & \multicolumn{1}{c}{ Service Element } & Index Expectation & Index Satisfaction & Gap \\
\hline 6 & Implementing Competencies & 3,68 & 3,28 & $(0,40)$ \\
\hline 7 & Executing Behavior & 3,77 & 3,13 & $(0,63)$ \\
\hline 8 & Service Notices & 3,92 & 3,22 & $(0,70)$ \\
\hline \multirow{2}{*}{9} & $\begin{array}{l}\text { Handling complaints, sugges- } \\
\text { tions and feedback }\end{array}$ & 3,63 & 3,05 & $(0,58)$ \\
\hline \multirow{2}{*}{} & Highest Scores & 3,97 & 3,28 & \\
\cline { 2 - 5 } & Lowest Score & 3,63 & 3,05 & $(\mathbf{0 , 6 5})$ \\
\cline { 2 - 5 } & Average IKM & 3,82 & 3,17 & $(\mathbf{1 6 , 1 9})$ \\
\cline { 2 - 5 } & Conversion Value & 95,51 & 79,32 & \\
\cline { 2 - 5 } & Quality of Service & $\mathrm{A}$ & $\mathrm{B}$ & \\
\hline
\end{tabular}

Source: Survey Results, Year 2017.

Based on Table 5 above the gap between expectations and satisfaction of IMB services averaged 16.19. That public expectation of IMB services exceeds that felt by the community. Result of Spiderweb analysis visually that the indicator of the IMB service requirements have a great distance. This shows that the gap in terms of service is relatively large. The smallest gap value is an indicator of the competence of the implementer. These results explain that the level of service satisfaction associated with the implementing competency is considered to be close to the Expectation Index. That the quality of IMB services related to the perceived implementing competence is close to the expectations of service users.

\section{Conformity Analysis Level of Service Interest}

Based on the analysis that has been done on the analysis of IKM, Expectation Index, and gap analysis, then further- more the analysis of conformity of importance level. This analysis is used to determine and map which elements or indicators of service are necessary and important for immediate improvement and improvement of performance. The degree of conformity analysis is done using Kartesius diagram analysis consisting of four quadrants. The quadrant describes the elements of service that are the priority of improvement; service elements that need to be maintained; service elements that need to be improved performance but not priority, and service elements that have been good but need to be maintained.

\section{Validity and Reliability Test}

Prior the analysis of IKM for the type of service SIUP first tested the validity and reliability. For the purposes of validity test on survey is taken respondents as many as 60 people. The test results of validity and reliability are described in the Table 6 below.

Table 6. Validity Test Result

\begin{tabular}{|c|c|c|c|c|}
\hline No & Service Elements & $\mathbf{R}$ & $\mathbf{r} \min$ & Result \\
\hline 1 & Terms & 0,30 & 0,47 & Valid \\
\hline 2 & Procedure & 0,30 & 0,67 & Valid \\
\hline 3 & Service Time & 0,30 & 0,55 & Valid \\
\hline 4 & Cost / Tariff & 0,30 & 0,70 & Valid \\
\hline 5 & Product Specification Type of Service & 0,30 & 0,63 & Valid \\
\hline
\end{tabular}


Journal Sampurasun : Interdisciplinary Studies for Cultural Heritage

Vol. 04, Number 02, December 2018

\begin{tabular}{clccc}
\hline No & \multicolumn{1}{c}{ Service Elements } & R & r min & Result \\
\hline 6 & Implementing Competencies & 0,30 & 0,51 & Valid \\
\hline 7 & Executing Behavior & 0,30 & 0,66 & Valid \\
\hline 8 & Service Notices & 0,30 & 0,58 & Valid \\
\hline 9 & $\begin{array}{l}\text { Handling complaints, suggestions } \\
\text { and feedback }\end{array}$ & 0,30 & 0,47 & Valid \\
\hline
\end{tabular}

Source: Survey Results, Year 2017.

\subsection{IKM Calculation Result of SIUP Service}

Calculation of SIUP service element at DPMPTSP consists of nine indicators.
The calculation of Satisfaction Index and Expectation Index can be seen in the table 7 below.

Table 7. Public Satisfaction Index (IKM) of Service Trade Business License (SIUP)

\begin{tabular}{|c|c|c|c|}
\hline No & Service Element & Index Expectation & Index Satisfaction \\
\hline 1 & Terms & 3,87 & 3,15 \\
\hline 2 & Procedure & 3,65 & 3,22 \\
\hline 3 & Service Time & 3,65 & 3,25 \\
\hline 4 & Cost / Tariff & 3,78 & 3,27 \\
\hline 5 & Product Specification Type of Service & 3,57 & 3,27 \\
\hline 6 & Implementing Competencies & 3,43 & 3,22 \\
\hline 7 & Executing Behavior & 3,77 & 3,08 \\
\hline 8 & Service Notices & 3,77 & 3,12 \\
\hline \multirow[t]{6}{*}{9} & Handling complaints, suggestions and feedback & 3,82 & 2,98 \\
\hline & Highest Scores & 3,87 & 3,27 \\
\hline & Lowest Score & 3,43 & 2,98 \\
\hline & Average IKM & 3,70 & 3,16 \\
\hline & Conversion Value & 92,41 & 79,23 \\
\hline & Quality of Service & A & B \\
\hline
\end{tabular}

\section{Source: Survey Results, Year 2017}

Based on the above table that the highest Expectation Index is located on the indicator of requirements, which is 3.87 . While the lowest expectation index is at the competency indicator is 3.43 . The highest value of IKM is located in the cost indicator and product specification type of service, ie each of 3.27. While the lowest IKM value lies / are on indicators of complaints handling, suggestions and input, which amounted to 2.98. Furthermore, based on the recapitulation of IKM value for SIUP service amounted to 3.16 or 79.23 (conversion result). 
Thus, IKM for SIUP services is included in category $\mathrm{B}$ or "service performs well".

\subsection{The Gap of Public Expectation on IMB Service Satisfaction at DPMPTSP}

To measure the level of public satisfaction with SIUP service Gap Analysis is done. The results of Gap Analysis SIUP service organized by DPMPTSP, Subang Regency, shown in the Table 8 below.

Table 8. The Gap Between Expectations and Public Satisfaction

\begin{tabular}{|c|c|c|c|c|}
\hline No & Service Element & Expectation Index & Satisfaction Index & Gap \\
\hline 1 & Terms & 3,87 & 3,15 & $(0,72)$ \\
\hline 2 & Procedure & 3,65 & 3,22 & $(0,43)$ \\
\hline 3 & Service Time & 3,65 & 3,25 & $(0,40)$ \\
\hline 4 & Cost / Tariff & 3,78 & 3,27 & $(0,52)$ \\
\hline 5 & $\begin{array}{llll}\begin{array}{l}\text { Product } \\
\text { Service }\end{array} & \text { Specification } & \text { Type of } \\
\end{array}$ & 3,57 & 3,27 & $(0,30)$ \\
\hline 6 & Implementing Competencies & 3,43 & 3,22 & $(0,21)$ \\
\hline 7 & Executing Behavior & 3,77 & 3,08 & $(0,68)$ \\
\hline 8 & Service Notices & 3,77 & 3,12 & $(0,65)$ \\
\hline \multirow[t]{6}{*}{9} & $\begin{array}{l}\text { Handling complaints, suggestions } \\
\text { and feedback }\end{array}$ & 3,82 & 2,98 & $(0,83)$ \\
\hline & Highest Scores & 3,87 & 3,27 & \\
\hline & Lowest Score & 3,43 & 2,98 & \\
\hline & Average IKM & 3,70 & 3,17 & $(0,53)$ \\
\hline & Conversion Value & 92,41 & 79,23 & $(13,18)$ \\
\hline & Quality of Service & $\mathrm{A}$ & $\mathrm{B}$ & \\
\hline
\end{tabular}

Source: Survey Results, Year 2017.

As shown in Table 8 that the gap between expectations and SIUP service satisfaction average of 13.18. These results show that community expectations of SIUP services provided by DPMPTSP, Subang Regency, still exceeds that felt by the community. Indicators of service that has the greatest gap value lies in the indicators of complaint handling, suggestions and feet back amount 0.83 . The results explain that the indicators of complaints handling, suggestions and feet back felt by the community are not yet close to expectations. While the service indicator that has the smallest gap value is the indicator of implementing competence, that is equal to 0.21 .

The gap between expectations and satisfaction of SIUP services perceived by the community based on Spiderweb analysis that indicator of complaint handling, suggestion and feet back in the context of service SIUP have far distance compared with other service indi- 
cator. This explains that the gap in complaints handling indicators, suggestions and feet back is still relatively large. While the service indicator that has the smallest gap value is an indicator of the competence of the implementer. These results explain that the level of satisfaction of service regarding the competence of the implementor is considered to be close to the Expectation Index. The quality of SIUP services related to the perceived implementing competence, is considered to be close to the expectations of service users.

\section{Conformity Analysis Level of Service Interest}

Based on various analyzes that have been done that is the analysis of IKM, Hope Index and gap analysis, hence next conducted the conformity analysis of importance level. The degree of conformity analysis uses a Kartesius diagram analysis consisting of 4 quadrants. From the analysis, Kartesius diagram for SIUP service unit at DPMPTSP can be explained as follows. In Quadrant A is an element of service that requires improvement and performance improve- ment with priority scale. The element indicators of SIUP services are requirements, conductors behavior, service announcements and indicators of complaints handling, advice and feet back. Quadrant B is an element of service whose service performance has been felt very well (feel satisfied). So the performance of the element of service must be maintained. The performance element indicators of SIUP services is the cost or tariff. Quadrant D is a service with satisfactory service performance and close to the expectations of the respondents. Therefore element of service must be maintained. Elements of service on the SIUP service unit in the quadrant is the procedure, service time, product specification type of service and indicators of competence implementor.

\section{Validity and Reliability Test}

Prior to the analysis of IKM for the type of IMB services, first tested the validity and reliability of data. For the purposes of validity test in this study taken respondents as many as 60 people. The test results of validity and reliability are described in the Table 9 below.

Table 9. Validity Test Result

\begin{tabular}{|c|c|c|c|c|}
\hline No & Service Element & $\mathbf{r}$ & $\mathbf{r} \min$ & Result \\
\hline 1 & Terms & 0,30 & 0,39 & Valid \\
\hline 2 & Procedure & 0,30 & 0,67 & Valid \\
\hline 3 & Service Time & 0,30 & 0,74 & Valid \\
\hline 4 & Cost / Tariff & 0,30 & 0,57 & Valid \\
\hline 5 & Product Specification Type of Service & 0,30 & 0,59 & Valid \\
\hline 6 & Implementing Competencies & 0,30 & 0,59 & Valid \\
\hline 7 & Executing Behavior & 0,30 & 0,35 & Valid \\
\hline 8 & Service Notices & 0,30 & 0,36 & Valid \\
\hline 9 & Handling complaints, suggestions and feedback & 0,30 & 0,41 & Valid \\
\hline
\end{tabular}


Journal Sampurasun : Interdisciplinary Studies for Cultural Heritage

Vol. 04, Number 02, December 2018

Source: Research Results, Year 2017

Based on the above Table 9 shows that Calculation of service element in service the element or service indicator that becomes the parameter of IKM is valid. of TDP at DPMPTSP Subang Regency, The level of reliability of this research can be seen in Table 10 below. data is in fairly reliable category.

\section{Result of Calculation of IKM Service of TDP}

Table 10. Public Satisfaction Index (IKM) Service of Company Registration Certificate (TDP)

\begin{tabular}{clcc}
\hline No & \multicolumn{1}{c}{ Service Element } & Expectation Index & Satisfaction Index \\
\hline 1 & Terms & 3,75 & 3,28 \\
\hline 2 & Procedure & 3,73 & 3,12 \\
\hline 3 & Service Time & 3,75 & 3,33 \\
\hline 4 & Cost / Tariff & 3,82 & 3,28 \\
\hline 5 & Product Specification Type of Service & 3,85 & 3,23 \\
\hline 6 & Implementing Competencies & 3,83 & 3,42 \\
\hline 7 & Executing Behavior & 3,80 & 3,13 \\
\hline 8 & Service Notices & 3,78 & 3,15 \\
\hline \multirow{2}{*}{9} & Handling complaints, suggestions & and feed- & 3,12 \\
& back & 3,72 & 3,42 \\
\hline \multirow{2}{*}{} & Highest Scores & 3,85 & 3,12 \\
\cline { 2 - 4 } & Lowest Score & 3,72 & 3,23 \\
\cline { 2 - 4 } & Average IKM & 3,78 & 80,66 \\
\cline { 2 - 4 } & Conversion Value & 94,44 & $\mathrm{~B}$ \\
\cline { 2 - 4 } & Quality of Service & $\mathrm{A}$ & \\
\hline
\end{tabular}

Source: Survey Results, Year 2017

Based on the above Table 11 the highest expectation index is located on the product specification indicator product, which is 3.85 . While the lowest expectation index is indicator of complaint handling, suggestion and input, that is equal to 3,72 . The highest value of SMEs is an indicator of the competence of implementers, amounting to 3.42 . While the lowest value of IKM is indicator of procedure and indicator of complaint handling, suggestion and input, that is each of 3,12 . The result of recapitulation of IKM value for service of Company Registration Certificate (TDP) based on 9 indicators, obtained result of 3,23 or 80,66 (result of conversion). Thus, IKM services of TDP are included in category B or "service performs well".

\subsection{The Gap of Public Expectation on TDP Service Satisfaction at DPMPTSP}

To measure the level of community satisfaction with TDP service, Gap Analysis was conducted. Gap Analysis Results from the TDP service held by DPMPTSP Subang Regency, shown in the Table 12 below. 
Journal Sampurasun : Interdisciplinary Studies for Cultural Heritage

Vol. 04, Number 02, December 2018

Table 12. The Gap Between Expectations and Public Satisfaction

\begin{tabular}{|c|c|c|c|c|}
\hline No & Service Element & Expectation Index & Satisfaction Index & Gap \\
\hline 1 & Terms & 3,75 & 3,28 & $(0,47)$ \\
\hline 2 & Procedure & 3,73 & 3,12 & $(0,62)$ \\
\hline 3 & Service Time & 3,75 & 3,33 & $(0,42)$ \\
\hline 4 & Cost / Tariff & 3,82 & 3,28 & $(0,53)$ \\
\hline 5 & $\begin{array}{l}\text { Product Specification Type of Ser- } \\
\text { vice }\end{array}$ & 3,85 & 3,23 & $(0,62)$ \\
\hline 6 & Implementing Competencies & 3,83 & 3,42 & $(0,41)$ \\
\hline 7 & Executing Behavior & 3,80 & 3,13 & $(0,67)$ \\
\hline 8 & Service Notices & 3,78 & 3,15 & $(0,63)$ \\
\hline \multirow[t]{6}{*}{9} & $\begin{array}{l}\text { Handling complaints, suggestions and } \\
\text { feedback }\end{array}$ & 3,72 & 3,12 & $(0,60)$ \\
\hline & Highest Scores & 3,85 & 3,42 & \\
\hline & Lowest Score & 3,72 & 3,12 & \\
\hline & Average IKM & 3,78 & 3,23 & $(0,55)$ \\
\hline & Conversion Value & 94,44 & 80,66 & $(13,78)$ \\
\hline & Quality of Service & $\mathrm{A}$ & B & \\
\hline
\end{tabular}

Source: Survey Results, Year 2017

Based on Table 12 above that the gap between expectations and satisfaction of TDP services averaged 13.78. These results indicate that community expectations for TDP services are still more than those perceived by the community. Indicator service that has the biggest gap value is indicator of executor behavior, that is equal to 0,67 . The results suggest that the implementing behavior indicators perceived by the community are not yet close to expectations. While the service indicator which has the smallest gap value is in the competency of implementing indicator, that is equal to 0,41 .

To clarify the gap between expectations and satisfaction of TDP services perceived by the community presented the results of Spiderweb analysis. Spi- derweb analysis shown that indicator of implementing behavior in the context of TDP service has a great distance. It illustrates that the gap of implementing behavior in the context of service is relatively large. The implementing competency indicator has the smallest gap value. These results indicate that the level of service satisfaction associated with the implementing competency is considered to be close to the Expectation Index. That the quality of TDP services related to the perceived implementing competence is close to the expectations of service users

\section{Conformity Analysis Level of Service Interest}

A suitability level analysis is used to determine the necessary and important 
service indicators for improvement in performance. This analysis uses Kartesius diagram analysis. From the analysis of Kartesius diagram on the TDP service unit in DPMPTSP is as follows. In Quadrant A is an element of service that requires improvement and performance improvement with priority scale. The element indicator of TDP service is an indicator of implementing behavior. Quadrant B is an element of service whose service performance has been felt very well. The performance of the service element must be maintained. The performance of service element from TDP service is cost/tariff indicator, product specification type of service and indicator of implementing competence. Quadrant C is a service with performance that needs improvement but not as a priority scale. The elements indicators of the TDP service unit in the quadrant are procedural indicators, service announcements and complaint handling indicators, suggestions and feet back. Quadrant D is a service with satisfactory service performance and close to the expectations of the respondents. Therefore, the element of service must be maintained. The service elements in the TDP service unit present in the quadrant are the indicator of the requirements and the indicator of service time.

\section{Validity and Reliability Test}

Prior IKM analysis for the type of Industrial Registration Service (TDI), first tested the validity and reliability of the data. The results of validity test and reliability of research data can be comprehensively described in the Table 13 below.

Table 13. Validity Test Result

\begin{tabular}{llccc}
\hline No & Service Element & $\mathbf{R}$ & r min & Result \\
\hline 1 & Terms & 0,30 & 0,55 & Valid \\
\hline 2 & Procedure & 0,30 & 0,67 & Valid \\
\hline 3 & Service Time & 0,30 & 0,52 & Valid \\
\hline 4 & Cost / Tariff & 0,30 & 0,60 & Valid \\
\hline 5 & Product Specification Type of Service & 0,30 & 0,57 & Valid \\
\hline 6 & Implementing Competencies & 0,30 & 0,63 & Valid \\
\hline 7 & Executing Behavior & 0,30 & 0,34 & Valid \\
\hline 8 & Service Notices & 0,30 & 0,54 & Valid \\
\hline 9 & Handling complaints, suggestions and feedback & 0,30 & 0,42 & Valid \\
\hline
\end{tabular}

Source: Research Results, Year 2017

Based on the above Table 13 that the element or service indicator that becomes the parameter of IKM is valid. Reliability test results can be seen in the Table 14 below.
IKM Calculation Result of TDI Service

Calculation of service element at TDI service at DPMPTSP. The result of cal- 
Journal Sampurasun : Interdisciplinary Studies for Cultural Heritage

Vol. 04, Number 02, December 2018

culation of IKM and Expectation Index

can be seen in table below;

Table 14. Public Satisfaction Index (IKM) Services of Industrial Registered License (TDI)

\begin{tabular}{|c|c|c|c|}
\hline No & Service Element & $\begin{array}{l}\text { Expectation In- } \\
\text { dex }\end{array}$ & Satisfaction Index \\
\hline 1 & Terms & 3,55 & 3,27 \\
\hline 2 & Procedure & 3,52 & 3,20 \\
\hline 3 & Service Time & 3,55 & 3,18 \\
\hline 4 & Cost / Tariff & 3,65 & 3,05 \\
\hline 5 & $\begin{array}{l}\text { Product Specification Type of } \\
\text { Service }\end{array}$ & 3,72 & 3,37 \\
\hline 6 & $\begin{array}{l}\text { Implementing Competen- } \\
\text { cies }\end{array}$ & 3,67 & 3,02 \\
\hline 7 & Executing Behavior & 3,68 & 3,32 \\
\hline 8 & Service Notices & 3,70 & 3,22 \\
\hline \multirow[t]{6}{*}{9} & $\begin{array}{l}\text { Handling complaints, suggestions } \\
\text { and feedback }\end{array}$ & 3,62 & 3,33 \\
\hline & Highest Scores & 3,72 & 3,37 \\
\hline & Lowest Score & 3,52 & 3,02 \\
\hline & Average IKM & 3,62 & 3,21 \\
\hline & Conversion Value & 90,60 & 80,34 \\
\hline & Quality of Service & $\mathrm{A}$ & B \\
\hline
\end{tabular}

\section{Source: Survey Results, Year 2017}

Based on the above Table 14 that the highest Expectation Index is on product indicator specification of service result, that is equal to 3,72 . The lowest expectation index lies in the indicator procedure, which is 3.52 . The highest value of IKM is indicator of product specification type of service, which is 3.37. While the lowest value of IKM is indicator of executor competence, that is equal to 3.02. Result of recapitulation of IKM value for TDI service obtained result equal to 3,21 or 80,34 (result of conversion). Thus, IKM for TDI services is included in category B or "service performing well".

\subsection{The Gap of Public Expectation on TDI Service Satisfaction at DPMPTSP}

To measure how the level of community satisfaction with TDI services conducted by DPMPTSP Gap Analysis was conducted. Gap Analysis Results from TDI services organized by DPMPTSP shown in the Table 15 below. 
Journal Sampurasun : Interdisciplinary Studies for Cultural Heritage

Vol. 04, Number 02, December 2018

Table 15. The Gap Between Expectations and Public Satisfaction

\begin{tabular}{|c|c|c|c|c|}
\hline No & Service Element & Expectation Index & Satisfaction Index & Gap \\
\hline 1 & Terms & 3,55 & 3,27 & $(0,28)$ \\
\hline 2 & Procedure & 3,52 & 3,20 & $(0,32)$ \\
\hline 3 & Service Time & 3,55 & 3,18 & $(0,37)$ \\
\hline 4 & Cost / Tariff & 3,65 & 3,05 & $(0,60)$ \\
\hline 5 & $\begin{array}{llll}\text { Product } & \text { Specification } & \text { Type of } \\
\text { Service } & & & \end{array}$ & 3,72 & 3,37 & $(0,35)$ \\
\hline 6 & Implementing Competencies & 3,67 & 3,02 & $(0,65)$ \\
\hline 7 & Executing Behavior & 3,68 & 3,32 & $(0,37)$ \\
\hline 8 & Service Notices & 3,70 & 3,22 & $(0,48)$ \\
\hline \multirow[t]{6}{*}{9} & $\begin{array}{l}\text { Handling complaints, sugestions } \\
\text { and feedback }\end{array}$ & 3,62 & 3,33 & $(0,28)$ \\
\hline & Highest Scores & 3,72 & 3,37 & \\
\hline & Lowest Score & 3,52 & 3,02 & \\
\hline & Average IKM & 3,62 & 3,21 & $(0,41)$ \\
\hline & Conversion Value & 90,60 & 80,34 & $(10,27)$ \\
\hline & Quality of Service & $\mathrm{A}$ & B & \\
\hline
\end{tabular}

\section{Source: Survey Results, Year 2017}

Based on Table 15 above, the gap between expectations and satisfaction of TDI service is an average of 0.41 or 10.27 (conversion result). The results show / show that people's expectation on TDI service still exceeds that felt by society. Indicator service that has the biggest gap value is the indicator of implementing competence, that is equal to 0,65 . The result shows that the competency indicator of TDI service is not yet close to expectation. While the service indicators that have the smallest value of the gap is the indicator of complaint handling requirements and indicators, suggestions and feet back, ie each of 0.28 .

Furthermore, to clarify how the gap between expectations and satisfaction of TDI services perceived by the following communities presented the results of Spiderweb analysis. Indicators of implementing competencies in the context of TDI services have far-reaching distance, as compared to other service indicators. This implies that the implementation competence gap in the context of TDI services is relatively large. While the requirements indicator and complaint handling, suggestions and feet back in the context of TDI services have the smallest gap values. These results mean that the level of service satisfaction is related to the requirements and handling of complaints, feet back and suggestions are considered to be close to the Expectation Index. Whereas the quality of TDI services regarding complaints requirements and handling, feedback and suggestions are already close to the expectations of service users. 


\section{Conformity Analysis Level of Service Interest}

A suitability level analysis is used to determine which elements or service indicators are necessary and necessary to improve and improve performance. This conformity level analysis uses Kartesius diagram analysis consisting of 4 quadrants. The results of TDI service unit analysis on DPMPTSP are as follows. Quadrant A is an element of service that requires improvement and performance improvement with priority scale. The element service is the indicator of cost / tariff and the competence of the implementer. Quadrant B is an element of service whose service perfor-

\section{Conclusion}

The achievement of the Community Satisfaction Index (IKM) of four types of public services at DPMPTSP in Subang Regency is good performance quality category. The public service expectation index in Subang DPMPTSP shows that the public still hopes for better public services. Based on the IKM survey, the highest expectation index value is IMB services. While the lowest expectation index value is TDI service.

There is a gap between the IKM expectations of the community satisfaction 2017.

\section{References}

Akinboade, A., Oludele, K., Chanceline., E., \& Mokwena, P., M. (2012). mance has been felt very well (feel satisfied) so it must be maintained. The performance of service element / indicator is indicator of product specification type of service, executor behavior and indicator of service announcement. Quadrant $\mathrm{C}$ is a service with performance that needs improvement and improvement but not as a priority scale. The element indicator of the TDI service unit in the $\mathrm{C}$ quadrant is the procedure indicator and service time. Quadrant D is a service with service performance that has been satisfactory and close to expectation so that element of service must be maintained. The service elements in the TDI service unit located in the quadrant are indicators of compliance requirements and handling, suggestions and feet back.

index. People want better service. Therefore, it is necessary to continue to improve service quality. Of the four types of services that are assessed, the types of services that have the largest gap value is IMB service. This means that services perceived by the community have not yet approached expectations, need to be improved in performance. The type of service that has the lowest gap value is the type of TDI service. There are novelty in the four public services provided by DPMPTSP, namely service that still exceeds what is felt by the community. The value of IKM in DPMPTSP is increasing compared to
An analysis of citizen satisfaction with public service delivery in the Seding district municipality of South 
Journal Sampurasun : Interdisciplinary Studies for Cultural Heritage

Vol. 04, Number 02, December 2018

Africa. International Journal of Social Economics,39, 3,182-199.

Alamsyah, K .(2017). Community satisfaction to regional public hospital Banjar city. Public Policy and Administration Research, 7 (5),16-29.

Alam, M. (2015). Integrating civil service reform with decentralization. A case study. Singapore: UNDP Global Centre for Public Service Excellence.

Brajaktari, E. (2016). Citizen engagement in public service delivery. The critical role of public officials. Singapore: UNDP Global Centre for Public Service Excellence.

Bricki, N., \& Green, J. (2017). A guide to using qualitative research metodology. Medicins Sons Frontiers: United Kingdom.

Bruce, Joyce,. (2009). Models of teaching (night edition). Yogyakarta: Pustaka Pelajar.

Doherty, T, L., \& Horne, T. (2002).Managing public servicesimplementing changes: a thoughtful approach to the practice of management. London:Routledge.

Ewing-Chow, M., \& Losari, J, J., (2015). Multiple authorisation: the legal complexity of desentralisasi in Indonesia and the potential contribu- tion of iias in reducing confusion. Indonesia Law Review, Vol. 3, pp. 241256.

Hancock, B., Ockleford, E.,\& Windrige, K.(2009). An introduction to quantitative research. The NIHR RDS EM/YH: United Kingdom.

Hardianto, W, T., \& Adiwidjaja, I. (2015). Public service model in building good governance culture of local government integrated with new public service (NPS). Public Policy and Administration Research, Vol.5 (9), pp.17-26.

Kotler, J.,P. (2003). Leading change. Harvard: Harvard Bussines School Press.

Osborne, D. (2007). Reinventing government: what a difference a strategy makes", Paper of Global Forum on Reinventing Government Building Trust in Government, 26-29 June, 2007, Vienna, Austria.

Parasuraman, A. (2000). Technology readiness index (TRI): a multipleitem scale to measure readiness to embrace new technologies. Journal of Service Research, 2(4), 307-320.

Ramseook-Munhurrun, P., LukeaBhiwajee, S, D., \& Naidoo, P. (2010) Service quality in the public sector. 
Journal Sampurasun : Interdisciplinary Studies for Cultural Heritage Vol. 04, Number 02, December 2018

International Journal of Management and Marketing Research, Vol. 3, No.1,pp.37-50.

Shah, A.(2005). Public sector governance and accountability series.public service delivery. Washington DC:The International Bank for Reconstruction and Development/The World Bank.
Vacaloupoulou, M., A, Tsiotras, G., \& Gotzamani, K. (2013). Implementing $\mathrm{CAF}$ in public administration. Best practices in Europe-obstacles and challenges. Benchmarking: An International Journal,20, 6, 744-764.

Wiig, K., M. (2002), "Knowledge management in public administration" Journal of Knowledge Management, 6, 3,224-239. 